\title{
PKM BUAH NAGA MERAH DI KECAMATAN SAMBOJA KABUPATEN KUTAI KARTANEGARA PROVINSI KALIMANTAN TIMUR
}

\author{
Heri Wijaya \\ Akademi Farmasi Samarinda \\ pusam_12@yahoo.com \\ Yulistia Budianti Soemarie \\ Akademi Farmasi Samarinda \\ yulistiabudianti@ymail.com \\ Nurul Fatimah \\ Akademi Farmasi Samarinda \\ nurulfatimah20@mail.ugm.ac.id
}

\begin{abstract}
Abstrak
Pelatihan ini dilaksanakan dalam rangka Program Kemitraan Masyarakat, dengan sasaran adalah masyarakat Kecamatan Samboja khususnya warga Desa Wonotirto dan Desa Beringin agung. Pelatihan dilakukan dalam lima (5) tahap. Metode pelatihan budidaya ini dengan melakukan pelatihan dan penyuluhan kepada peserta tentang budidaya tanaman buah naga merah, penanganan virus dan penanganan paska panen, proses pembuatan sirup dan ice cream dari daging buah naga merah, proses pengolahan saos dan saos pedas dari limbah kulit buah naga merah, Proses pengemasan produk olahan, dan cara analisis ekonomi dan strategi pemasaran.

Peserta dibagi menjadi 2 kelompok. Kelompok pertama adalah petani buah naga dan kelompok kedua adalah ibu-ibu PKK. Kegiatan pertama dilakukan dengan mengundang narasumber dari Dinas Tanaman Pangan dan Hortikultura.Penyampaian materi dengan metode ceramah dilakukan di dalam ruangan yang dilanjutkan dengan diskusi dan praktek yang dilakukan langsung oleh peserta pelatihan dengan dibimbing oleh pemateri.
\end{abstract}

Kata Kunci: Buah Naga, Pelatihan, Samboja 


\section{Pendahuluan}

Samboja merupakan sebuah Kecamatan yang terletak di wilayah pesisir Kabupaten Kutai Kartanegara, Provinsi Kalimantan Timur. Kecamatan Samboja menjadi Kecamatan yang terletak paling selatan yang berjarak sekitar $108 \mathrm{~km}$ dari pusat Kabupaten Kutai Kartanegara (Tenggaromg) dan 93 km dari ibukota Provinsi Kalimantan Timur, yaitu Samarinda

Samboja adalah wilayah penghasil minyak bumi dan gas alam (migas) yang sangat penting bagi Kutai Kartanegara. Selain Minyak Bumi dan Gas Alam, banyak penduduk di Samboja juga memanfaatkan lahan dibidang perkebunan. Salah satu tanaman yang dibudidayakan oleh penduduk Samboja adalah Buah Naga Merah (Hylocereus costaricensis).Tanaman ini masuk ke kawasan Indocina (Vietnam) sebagai tanaman hias karena penampilannya yang unik berbunga indah dan berbuah merah, mengilap dan bersirip (Bowman, 2008). Beberapa manfaat dari mengkonsumsi buah naga merah adalah dapat meningkatkan sistem kekebalan tubuh, menurunkan kolesterol, meredakan panas dalam, memperlancar buang air besar, menambah nafsu makan dan dapat mencegah kanker (Hardjadinata, 2010). Peluang usaha buah naga sangat menjanjikan, tidak saja dapat digunakan untuk konsumsi segar tetapi juga dapat dibuat sebagai produk yang berkhasiat untuk kesehatan

Salah satu sentra produksi buah naga merah di daerah Kalimantan Timur terletak di Kecamatan Samboja Kabupaten Kutai Kartanegara. Daerah ini sebagian besar penduduknya memiliki mata pencaharian sebagai petani buah naga merah. Mitra pertama pada program ini berprofesi sebagai petani yang memiliki lahan buah naga merah di Desa Wonotirto. Mitra dua pada program ini adalah para ibu PKK yang berada di Desa Beringin Agung. Permasalahan yang dihadapi oleh kedua mitra yaitu adanya virus yang menyerang batang pohon buah naga merah, minimnya pengetahuan mengenai budidaya, pengolahan produk serta pengolahan limbah (kulit) dari buah naga merah, minimnya pengetahuan mengenai pemasaran produk serta belum adanya teknologi tepat guna dalam pengemasan produk buah naga merah.

Tujuan pelatihan dan pendampingan budidaya buah naga merah serta penerapan teknologi pasca panen adalah:

1. Petani buah naga merah memiliki cukup pengetahuan dan keterampilan tentang cara mengatasi virus yang menyerang batang pohon buah naga merah.

2. Petani buah naga merah yang memiliki cukup pengetahuan dan keterampilan tentang tata cara budidaya dan pemberian nutrisi dari buah naga merah sehingga terjadi peningkatan produktivitas tanaman.

3. Petani buah naga merah dan ibu PKK memiliki kemampuan dalam penerapan teknologi paska panen.

4. Petani buah naga merah dan ibu PKK memiliki usaha baru, yaitu usaha memasarkan produk olahan dari buah naga merah.

\section{Metode}

Pelatihan ini dilaksanakan dengan cara menjalin kerjasama antara Tim Pengusul PKM dengan petani buah naga merah sebagai mitra pertama dan Ibu-Ibu PKK sebagai mitra kedua. Tim Pengusul PKM bertindak sebagai Tim pelatih (trainner) dan pendamping, sedangkan petani buah naga merah beserta Ibu-Ibu PKK berperan sebagai peserta pelatihan dan pendampingan. Metode pelatihan dilakukan secara klasikal dengan metode ceramah, diskusi dan praktek. 


\section{Jurnal Abdimas Mahakam}

https://journal.uwgm.ac.id/index.php/abdimasmahakam

Online ISSN : 2549-5755

Juni 2018, Vol.2 No. 2

Pelaksanaan diawali dengan tahap sebagai berikut:

A. Melakukan survei lokasi dan kerja sama dengan warga di Desa Wonotirto dan Beringin Agung Hal ini dilakukan untuk menggali informasi terhadap permasalahan-permasalahan yang terdapat dikedua desa tersebut. Selain menggali informasi juga disampaikan maksud dan tujuan dari pelatihan budidaya serta meminta izin merealisasikan pelatihan ini di desa tersebut. Selain itu, disampaikan teknis kegiatan yang akan dilakukan yaitu berupa pelatihan dan penyuluhan budidaya buah naga merah serta penerapan teknologi pasca panen.

B. Persiapan alat dan bahan

Tahap selanjutnya yang akan dilakukan adalah menyiapkan alat dan bahan yang akan digunakan. Alat dan bahan yang perlu disiapkan diantaranya adalah pana dandang $22 \mathrm{~cm}$, panci $22 \mathrm{~cm}$, pisau, Irus, Saringan, Baskom, wadah segi, gelas bola 2, sendok agar, gelas ice cream, mixer, timbangan, blender, kompor gas, tabung gas, corong, gelas takar, susu cair full cream, minyak goreng, gula pasir, yogurt, penyedap rasa, cuka, bawang putih, cabe rawit, bawang bombay, garam, buah naga merah.

C. Menyusun jadwal kegiatan

Pelatihan dilaksanakan dalam 5 tahap, tahap pertama dilakukan pada tanggal 25 Mei 2017, tahap kedua pada tanggal 23 Februari 2018, tahap ketiga pada tanggal 10 Maret 2018, tahap keempat pada tanggal 7 April 2018, tahap kelima pada tanggal 21 April 2018

D. Menentukan Materi Kegiatan

Materi yang akan diberikan kepada petani buah naga dan ibu-ibu PKK adalah:

1. Budidaya tanaman buah naga merah, penanganan virus dan penanganan paska panen

2. Nilai gizi dan khasiat kandungan buah naga merah bagi kesehatan

3. Proses pembuatan sirup dan ice cream dari daging buah naga merah

4. Proses pengolahan saos dan saos pedas dari limbah kulit buah naga merah

5. Proses pengemasan produk olahan dan sterilisasi

6. Cara analisis ekonomi dan strategi pemasaran

\section{Hasil dan Pembahasan}

Pelatihan budidaya buah naga dan penerapan pasca panen dilakukan kepada para petani buah naga dan ibu-ibu PKK di Desa Wonotirto dan Desa Beringin Agung. Pelatihan dibagi menjadi 5 Tahap. Tahap pertama adalah survei lokasi dan wawancara, dilaksanakan pada tanggal 25 - 26 Mei 2017. Pada tahap ini dapat digali beberapa permasalahan yang terdapat di kedua desa tersebut, diantaranya adalah: adanya virus yang menyerang bagian batang pohon dari buah naga merah, belum adanya pelatihan dan pendampingan para petani untuk budidaya buah naga merah, buah naga merah hanya dijual dalam bentuk buah segar, belum ada produk lain yang dihasilkan dari buah naga merah. belum ada solusi untuk menghadapi limbah kulit buah naga merah pada saat produksi melimpah yaitu saat panen raya dan terakhir tidak adanya manajemen pemasaran yang baik dan mampu mendukung penjualan buah naga merah dan produknya. Survey dan wawancara dapat dilihat pada gambar 1
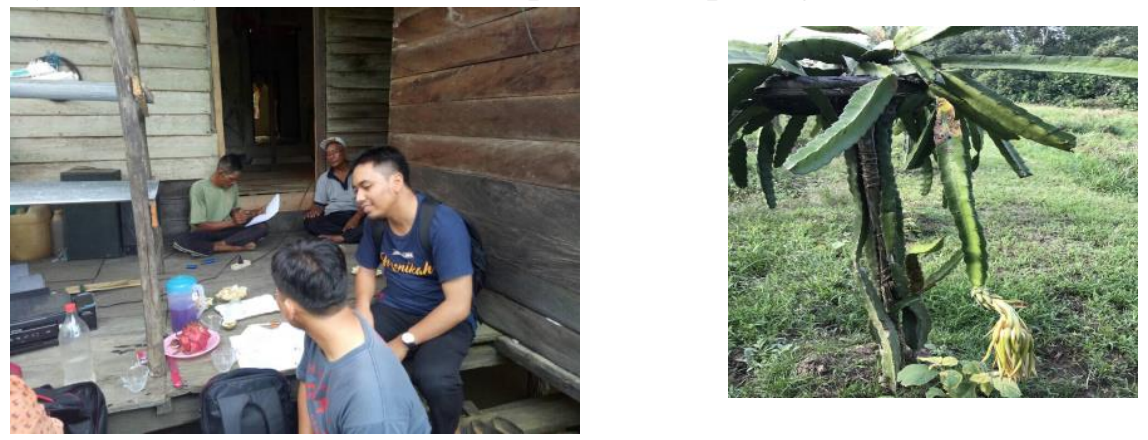


\section{Jurnal Abdimas Mahakam}

https://journal.uwgm.ac.id/index.php/abdimasmahakam

Online ISSN : 2549-5755

Juni 2018, Vol.2 No. 2

Tahap kedua dilaksanakan pada tanggal 23 Februari 2018 dengan tema Budidaya tanaman buah naga merah, penanganan virus dan penanganan paska panen. Pada tahap ini sasaran utama adalah Bapak-bapak petani buah naga dan menghadirkan narasumber dari Dinas Pertanian Tanaman Pangan dan Hortikultura. Selama pemberian materi, peserta pelatihan sangat antusias, hal ini dapat dilihat dari banyaknya pertanyaan yang masuk, pemberian materi dapat dilihat pada gambar 2 .
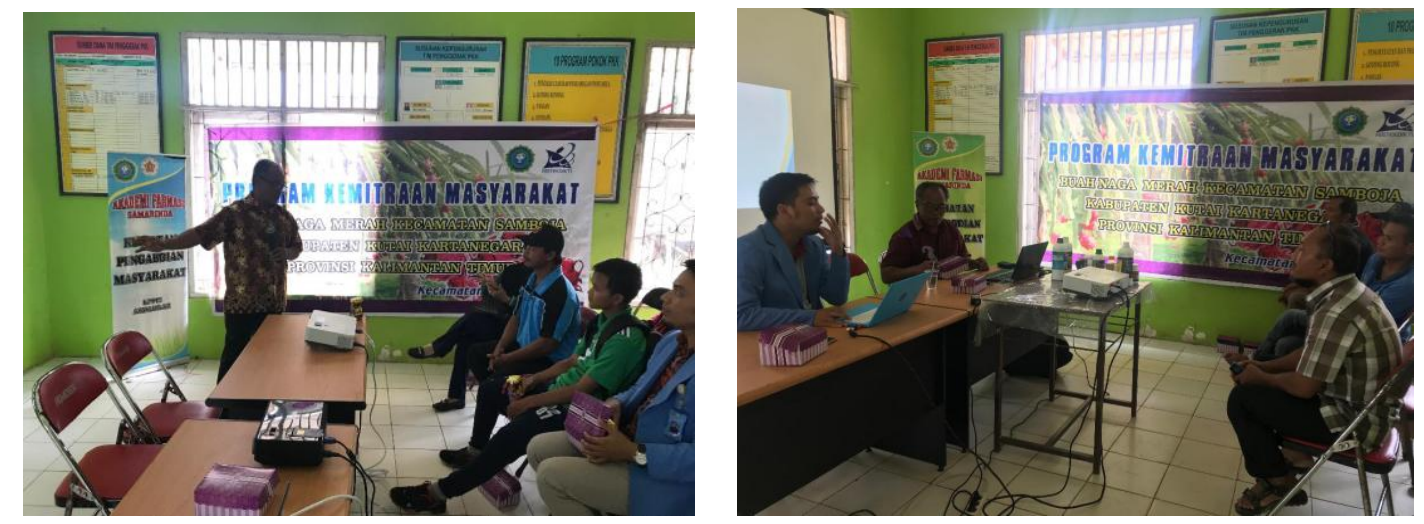

Hal-hal yang diajarkan pada materi ini adalah tentang budidaya buah naga merah, pembuatan pupuk organik dan non organik, kemudian penanganan terhadap penyakit dan hama tanaman, terakhir tentang tata cara pemanenan.

Tahap ketiga dilaksanakan pada tanggal 10 - 11 Maret 2018 dengan tema nilai gizi dan khasiat kandungan buah naga merah bagi kesehatan serta proses pembuatan sirup dan ice cream dari daging buah naga merah (penerapan teknologi pasca panen).

Dikesempatan kedua ini target peserta adalah Ibu-ibu PKK dari kedua desa, antusiasme peserta bagus karena mendapatkan langsung pelatihan pembuatan produk yang sangat bermanfaat. Pemberian materi pelatihan dapat dilihat pada gambar 3.
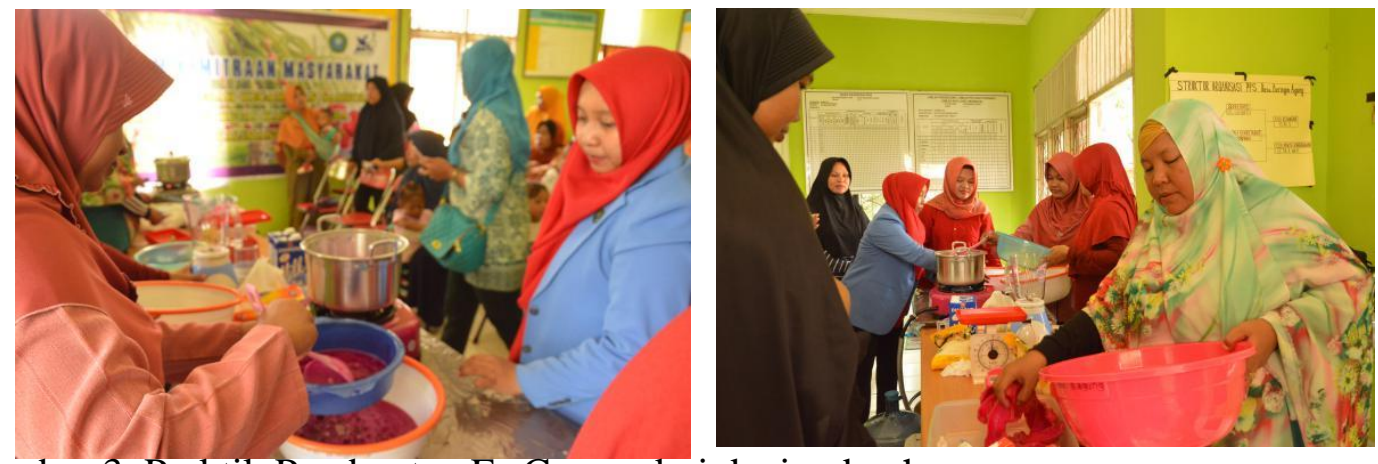

Gambar 3. Praktik Pembuatan Es Cream dari daging buah naga

Materi keempat dilaksanakan pada tanggal 10 - 11 Maret 2018 dengan tema Proses pengolahan saos dan saos pedas dari limbah kulit buah naga merah dan Proses pengemasan produk olahan dan sterilisasi. Materi ini peserta sangat antusias karena baru pertama kali diperkenalkan bahwa kulit buah naga dapat diolah menjadi produk saos. selama ini kulit buah naga tidak terlalu diperhatikan, ketika mengkonsumsi buah naga kulitnya dibuang, padahal kulit buah naga masih dapat diolah menjadi produk yang memiliki nilai jual cukup tinggi Pemberian materi pelatihan dapat dilihat pada gambar 4 


\section{Jurnal Abdimas Mahakam}

https://journal.uwgm.ac.id/index.php/abdimasmahakam

Online ISSN : 2549-5755

Juni 2018, Vol.2 No. 2
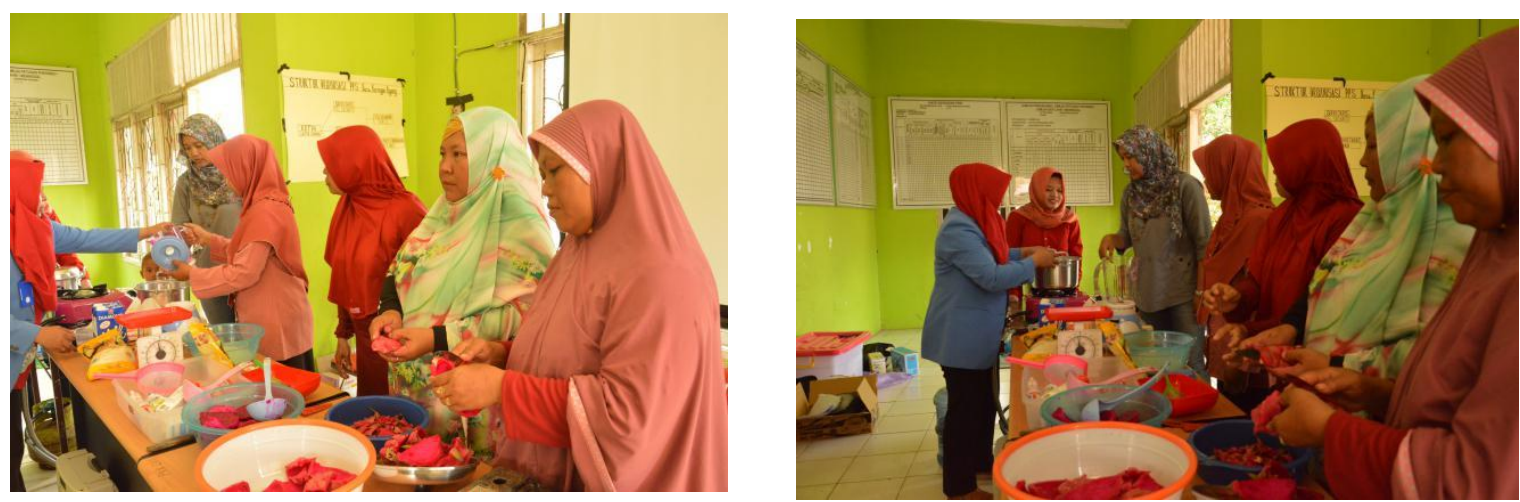

Gambar 4. Praktik pembuatan saos dari kulit buah naga

Materi kelima dilaksanakan pada tanggal 21 April 2018 dengan tema Analisis Ekonomi Usaha dan Strategi Pemasaran Produk. Diharapkan dari materi ini peserta mampu lebih memaksimalkan pendapatan dari produk-produk yang telah diciptakan, Pemberian materi pelatihan dapat dilihat pada gambar 5
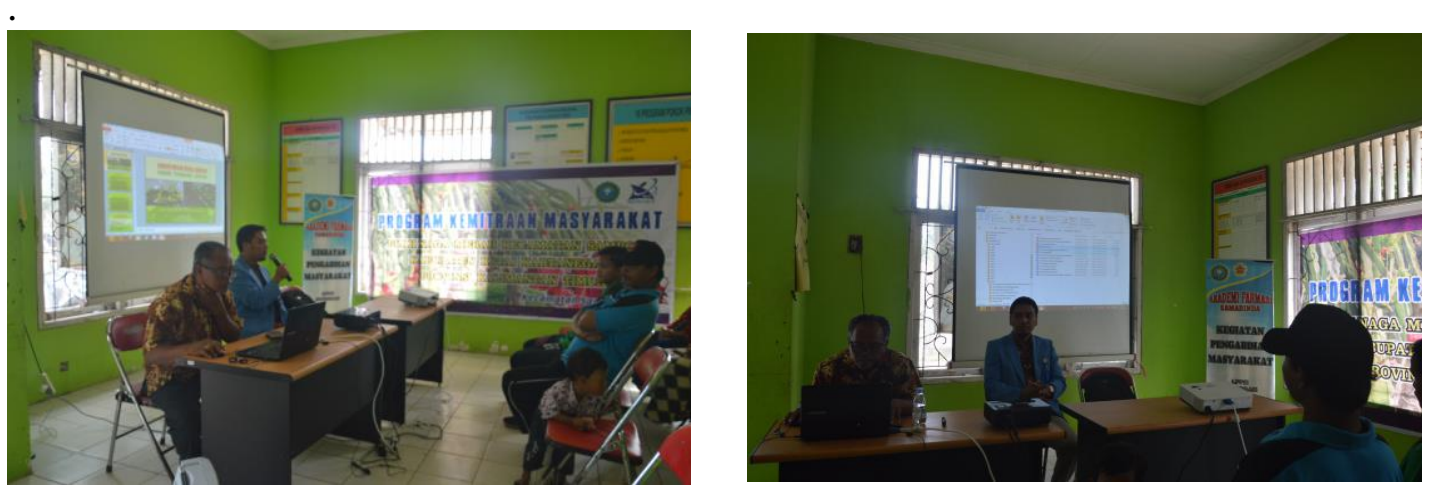

Gambar 5. pemberian materi tentang analisis ekonomi dan pemasaran

\section{Simpulan dan rekomendasi}

1. Peserta pelatihan mendapatkan solusi atas permasalahan yang dihadapi

2. Petani buah naga merah kembali bersemangat menggarap kembali lahannya karena informasi dan pelatihan yang didapat memberikan pemahaman yang menyeluruh tentang budidaya buah naga

3. Ibu-ibu PKK mendapatkan bekal pengetahuan bahwa kulit buah naga dan daging buah naga dapat diolah menjadi produk yang memiliki nilai tambah secara ekonomi 


\section{Jurnal Abdimas Mahakam}

https://journal.uwgm.ac.id/index.php/abdimasmahakam

Online ISSN : 2549-5755

Juni 2018, Vol.2 No. 2

\section{Daftar Pustaka}

Bowman JE. (2008). Good agricultural practices and Eurep GAP certification for Vietnam's small farmer-based dragon fruit industry. Joint Annual Meeting, Celebrating the International Year of Planet Earth. George R. Brown Convention Center, Houston, Texas.

Hardjadinata. (2010). Budidaya Buah Naga Super Red secara Organik. Penebar Swadaya, Bogor. 